who, by training and experience, is most familiar with the neighbouring West Indian seas and all that pertains to fisheries work upon them. Perusal of Dr. Duerden's paper is convincing as to the urgency of this matter, and we consider that the Government and those in charge of the Agricultural Department of the West Indies would be well advised did they provide, properly equipped, a laboratory of which he should be put in charge. To do so would be but to give the Department equal chances with others under Imperial control, to which it is closely akin.

Concerning the economic zoology of the West Indian seas then, everything tends to show that at the present time circumstances so combine that it may be said all is ripe for the initiation of a new departure, under which systematic work and organisation, guided by the light of science, may be profitably brought to bear. The local Press are advocating this course, and the special publication of Dr. Duerden's paper is the expression on the part of those best competent to judge of its desirability. Given this, and the scientific knowledge of the movements and life-histories of the denizens of the seas which would thus be obtainable, the hatcheries, curing-houses, wharves and trading-fleet would follow in due course; and it is certain that a moderate amount of assistance bestowed in the direction we have indicated might be the means of placing the depressed colonies in an improved position, and of thereby lessening their constantlyrecurring charge upon the mother country.

\section{THE LATE MR. SEEBOHM'S TRAVELS IN ARCTIC EUROPE AND ASIA.}

THE two well-known volumes, respectively entitled "Siberia in Europe" and "Siberia in Asia," in which Mr. Seebohm described his bird-nesting expeditions to the Petchora (I 875) and Yenesei (1877) valleys, having long been out of print, the author determined to combine (and to some extent condense) the two narratives, and to issue them in single volume form. The greater portion of this task had been accomplished when it was unhappily brought to an abrupt close by the untimely death of the talented author. Its completion was thus of necessity left to another hand. Although the editor has not thought fit to make his identity known to the public, he may be congratulated on the tact and skill with which he has carried out his share of the work.

In one respect, and one respect only, are we disposed to find fault with the editor; and this in regard to the title chosen for the volume. In this respect, indeed, both author and editor are singularly unfortunate. "Siberia in Europe," the title of the first volume of the original work, is a geographical absurdity, and "Birds of Siberia" is but little, if at all, better. For, in the first place, at least half of the tract of country through which the author travelled has not the faintest shadow of a claim to be termed "Siberia," and, secondly, birds form by no means the sole topic on which the author discourses. "Egghunting in high latitudes," or some such title, would, we think, have been a far preferable designation.

Since Mr. Seebohm's account of his journey along the Yenesei was reviewed at considerable length in these columns when the original work was published, a very brief notice will suffice on the present occasion. The author's main object was to obtain nests, eggs and young of birds whose breeding habits were previously almost or entirely unknown; and his success in discovering the breeding places of the grey plover, little stint and other kinds of his favourite "Charadriidæe" are now matters of history. Migration was also a favourite subject of study and speculation on the part of

1 "The Birds of Siberia ; a Record of a Naturalist's Visit to the Valleys of the Petchora and Yenesei." By Henry Seebobm. Pp. xix + 512. Illustrated. (London: Murray, rgor). Price r2s. net.

$$
\text { NO. } x 645 \text {, VOL. } 64]
$$

Mr. Seebohm; and although we may be unable to assent to all his views and opinions with regard to this phenomenon, his account (p. 203) of the rush of migrating birds on Heligoland must remain fresh and interesting for all time.

"From the darkness in the east," he writes, "clouds of birds were continually emerging in an uninterrupted stream ; a few swerved from their course, fluttered for a moment as if dazzled by the light, and then gradually vanished with the rest in the western gloom. . . I should be afraid to hazard a guess as to the hundreds of thousands that must have passed in a couple of hours . . . . The scene from the balcony of the lighthouse was equally interesting; in every direction birds were flying like a swarm of bees, and every few seconds one flew against the glass."

And Mr. Seebohm is equally happy when describing the habits of the birds and their young on the tundra, which formed the main object of his expeditions. The most striking illustrations in the book are undoubtedly those of the nest and young of the grey plover and little stint, but as these appeared in NATURE on a former occasion they are not repeated here, and we prefer to

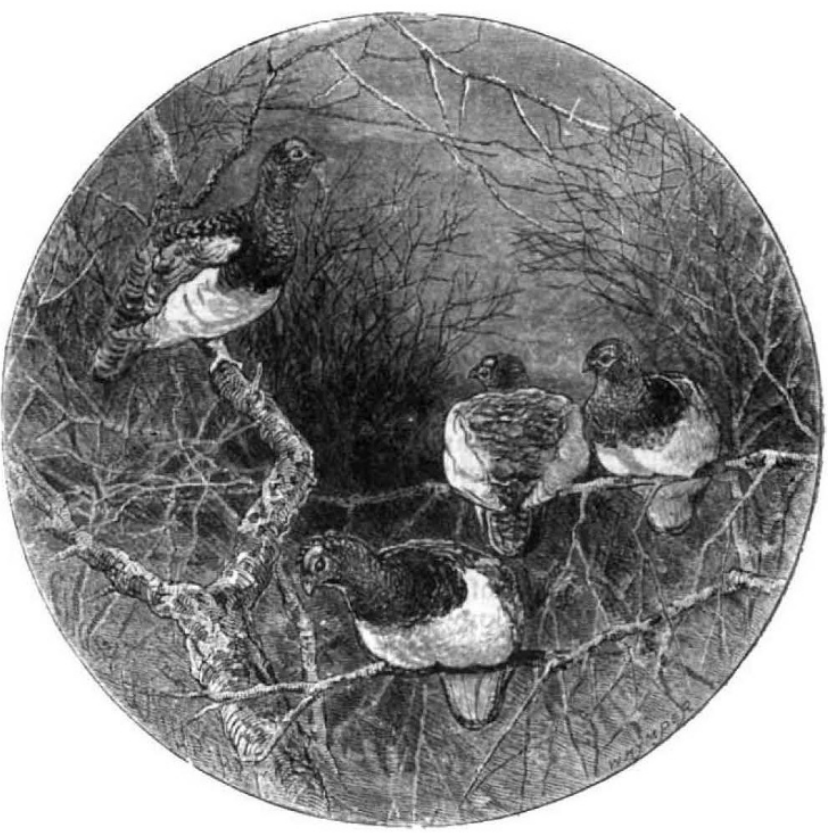

FIG. 1.-A group of willow-grouse. (From "The Birds of Siberia.")

give, as an example of Mr. Whymper's illustrations, the exquisite cut of willow-grouse which stands at the head of chapter xii.

But, as we have already indicated, Mr. Seebohm by no means confined his attention to birds, and his notes on the Samoyedes of the Petchora should form interesting reading to all students of anthropology, while his observations on reindeer can scarcely fail to attract all those who make a special study of the deer tribe. The sportsman, too, will find much interesting matter in many of Mr. Seebohm's pages.

Our opinion of the manner in which the editor has carried out his task has been already expressed; but we think he would have been wiser had he cut out the penultimate paragraph of the last chapter, which contains certain very unnecessary reflections on the mode of zoological work in vogue in this country.

As an interesting and well-written account of two adventurous journeys through little-known mosquitohaunted regions, the work should attract a large circle of readers. 